\title{
DESIGN OF A POWERTRAIN BASED ON SYNCHRONOUS ELECTRIC DRIVES USED IN VEHICLES
}

\section{MAREK ŽÁK}

Mendel University in Brno, Department of Engineering and Automobile Transport, Zemědělská 1, 61300 Brno, Tel.: +420 545132 942, E-mail: marek.zak@mendelu.cz

\section{JIŘí ČUPERA}

Mendel University in Brno, Department of Engineering and Automobile Transport, Zemědělská 1, 61300 Brno, Tel.: +420 545132 942, E-mail: xcupera@node.mendelu.cz

\section{MARTIN FAJMAN}

Mendel University in Brno, Department of Engineering and Automobile transport, Zemědělská 1, 61300 Brno, Tel.: +420 545133 327, E-mail: fajman@mendelu.cz

\section{SHRNUTí}

Článek pojednává o konverzi čtyřkolového vozidla pro volný čas se zážehovým motorem na pohon ryze elektrický. Snahou vývoje bylo vytvořit konstrukční řešení bez významných zásahů do rámu vozidla. Byly zvažovány rozličné varianty instalace pohonu. Typický způsob instalace je výměna spalovacího motoru za motor elektrický v pưvodním umístění. Pomalu jedoucí vozidla však mohou $s$ výhodou využívat také instalaci v ráfku kola. Byly vytvořeny obě varianty. Pro zkoušení vlastností obou variant byly vytvořeny zkušební metodiky na válcovém dynamometru i v silničním provozu. Hlavním účelem zkoušení bylo zejména monitorování elektrických vlastností. Zaznamenávány byly hodnoty hnací síly, rychlosti, vypočteného výkonu, napětí i proudu. Dưraz byl kladen i na stanovení dojezdu z Li-Pol akumulátorů a spolehlivost systému rekuperace.

\section{KLIĆCOV́ SLOVA: ELEKTRICKÉ VOZIDLO, SYNCHRONNÍ POHON, ELEKTRICKÉ POHONNÉ ÚSTROJÍ}

\section{ABSTRACT}

This paper deals with designing the conversion of a common on-road quad equipped with spark ignition engine to a pure electric drive. The aim of the development work was to create a design solution without making significant changes to the chassis. We considered several variants of powertrain installation. In general, two possibilities of electric drive design are used. Typically, the electric drive is mounted in place of an IC engine. Slow moving vehicles may have electric drives installed in the rims. We tested both variants. Therefore, to determine the properties of the mentioned variants we had to carry out simulation tests on a chassis dynamometer as well as road load tests. The main testing procedures consisted of driving cycles with the monitoring of electric parameters. Important values such as driving force, running speed, calculated power, battery voltage and used current were acquired. A fundamental part of the testing also consisted of monitoring the durability of the used Li-Pol batteries, and the reliability of the charging system with the support of regenerative braking.

\section{KEYWORDS: ELECTRIC VEHICLE, SYNCHRONOUS DRIVE, ELECTRIC POWERTRAIN}

\section{INTRODUCTION}

Vehicles powered with electric drives, also termed EV, are slowly becoming essential for the automotive industry. It is no wonder, simple electric vehicles were first developed in the mid-1 $19^{\text {th }}$ century. At that time electricity was the preferred propulsion method for vehicles. As vehicles developed further the internal combustion engine overtook the electric motor for vehicle propulsion. Over the last two decades, the environmental impacts of IC engines have led to renewed interest in electric drives for all categories of vehicles. The main reasons are requirements for lower vehicle emissions and the usage of an alternative renewable propellant source [3]. There are three categories of vehicles using electric drives. Mild hybrids are cars equipped with an electromotor used only as support for the combustion engine. It helps with the car acceleration, on start-up and cuts 


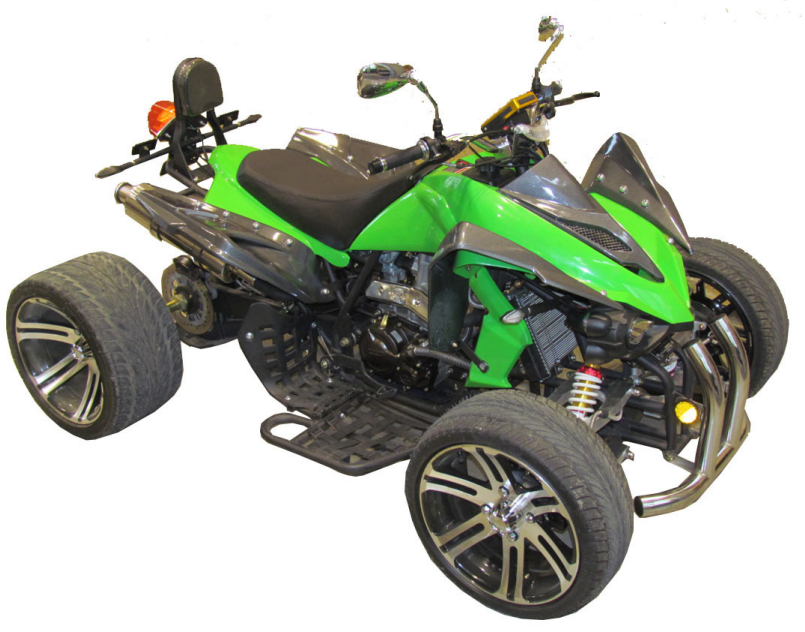

FIGURE 1: Quad Jinling JLA-21B.

OBRÁZEK 1: Čtyřkolové vozidlo Jinling JLA-21B.

down emissions in transitional modes. Full hybrids use electric motors as an adequate drive. The vehicle can be driven by an electric drive using electricity from accumulators (zero emissions) and when the battery voltage drops below a certain level the combustion engine starts up. Its power can be fed directly to drive the wheels, or the motor can work as a generator that recharges the accumulators. The third type is the full electric

TABLE 1: PERM PMS 100 - electric drive technical description. TABULKA 1: PERM PMS 100 - technický popis elektrického pohonu

\begin{tabular}{lll}
\hline ITEM & VALUE & REMARK \\
\hline Rated voltage & $48 \mathrm{~V} \mathrm{DC}$ & \\
\hline Maximal drive speed & $6000 \mathrm{1/min}$ & \\
\hline Rated Power / Torque & $2.7 \mathrm{~kW} \mathrm{/} \mathrm{4.3} \mathrm{Nm}$ & \\
\hline Peak Torque & $20 \mathrm{Nm}$ & $\begin{array}{l}\text { Pulse-Peak torque only up } \\
\text { to } 30 \% \text { of rated rpm }\end{array}$ \\
\hline $\begin{array}{l}\text { Motor Impulse- } \\
\text { torque }\end{array}$ & $\sim 24 \mathrm{Nm}$ & $\begin{array}{l}\text { Impulse-torque for max. } \\
0.5 \mathrm{~s} \text { and rpm }<501 / \mathrm{min}\end{array}$ \\
\hline & $\begin{array}{l}\text { Analog Hall } \\
\text { sensors (sin/ } \\
\text { cos); Resolver or } \\
\text { Encoder }\end{array}$ & $\begin{array}{l}\text { Depending on controller } \\
\text { specifications }\end{array}$ \\
\hline Weight & Approx. 5.8 kg & $\begin{array}{l}\text { Incl. sin/cos Encoder, } \\
\text { without break }\end{array}$ \\
\hline
\end{tabular}

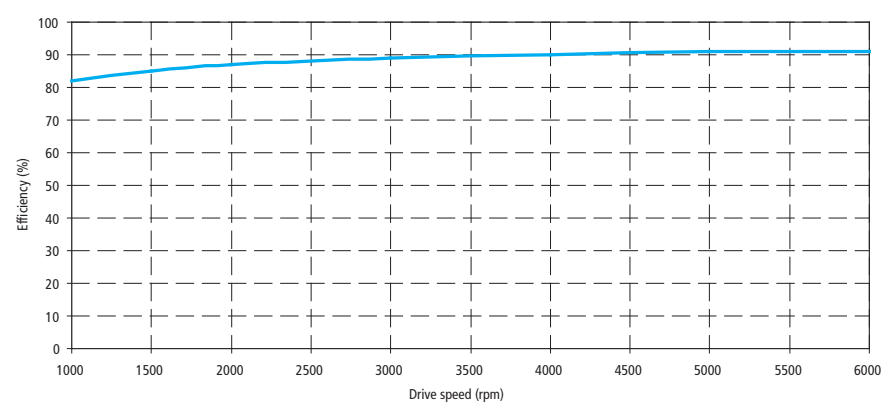

FIGURE 2: Efficiency of PERM PMS 100 OBRÁZEK 2: Účinnost pohonu PERM PMS 100

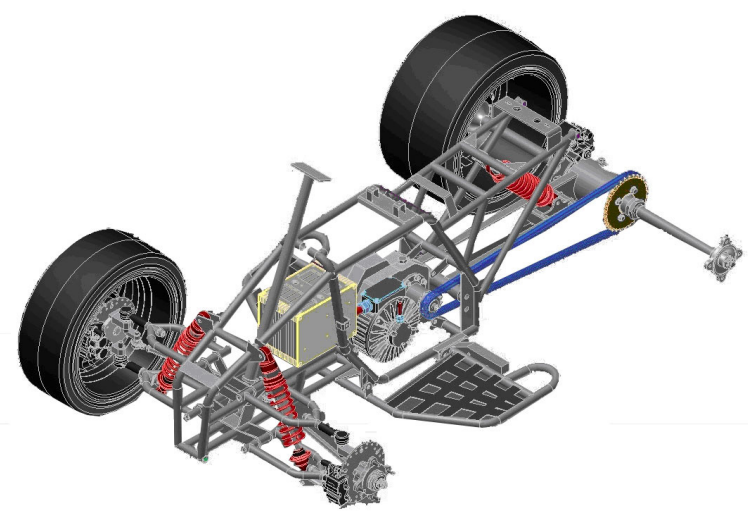

FIGURE 3: CAD model - a quad with PERM drive

OBRÁZEK 3: CAD model - čtyřkolové vozidlo s pohonem PERM

car, which uses just batteries as its energy source. Probably the most progressive is the full hybrid category [6]. The usage of the combustion engine or micro-turbine as a power generator is a good alternative to heavy and expensive accumulators. This is despite the fact that the efficiency of these units is the same or a little bit lower than the efficiency of standard powertrain units with a combustion engine [1], [2]. Contributions are skipping the gearbox as an expensive and complicated construction element, and are lowering the engine emissions by work in a stable mode without transient regimes [5]. There are still many problems obstructing a massive expansion of full electric cars: a lack of suitable traction powertrains from the point of view of construction and parameters (improper characteristics - torque, rpm, enormous weight, requirement of gears, etc.). When lead accumulators are used, the price is acceptable but the weight is enormous, more power is needed and more capacity as well. Substituting lead ones with Li-polymer can reduce the weight by up to $60 \%$, but they are still too expensive.

\section{MATERIALS AND METHODS}

The following text presents the project of the Mendel University in Brno (Faculty of Agriculture - Department of Engineering and Automobile Transport) and the company TREMONDI, which is involved in building and testing electric quad prototypes. Together with TREMONDI, we decided to use the Jinling JLA-21B quad (Figure 1), as a suitable platform for the prototype vehicle. Key considerations in making this decision were:

1. Price of the vehicle compared to the project budget.

2. Accessibility and price of spare parts if needed.

3. Hypothetical electric drive power similar to the power of the combustion engine.

4. Simple attachment to rolling chassis dynamometer. 


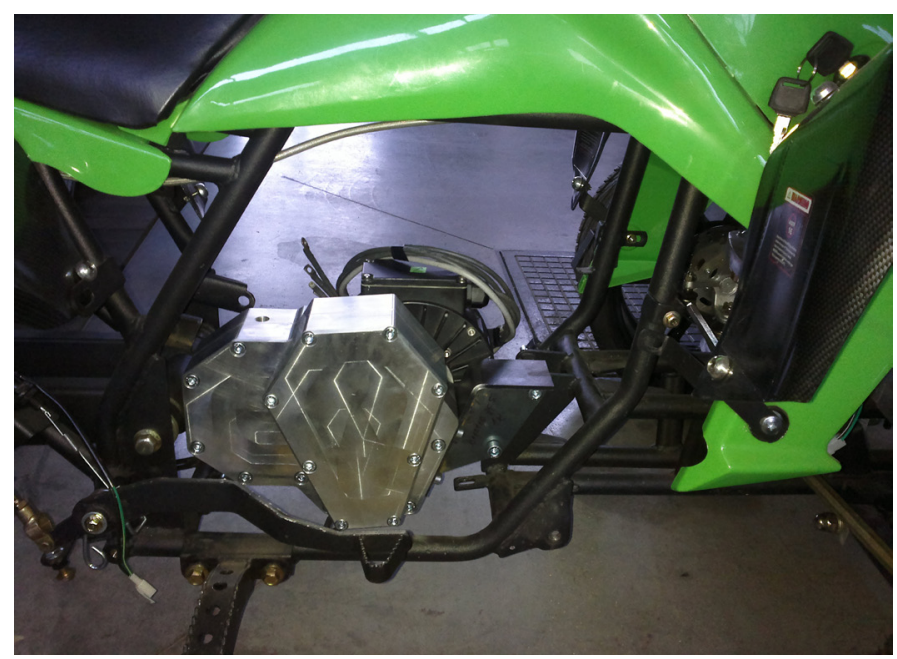

FIGURE 4: PERM PMS 100 with gearbox (gearbox ratio 7.05; chain ratio 2.58; final ratio 18.19 )

OBRÁZEK 4: PERM PMS 100 s převodovkou (převodový poměr 7.05; převod řetězem 2.58; koncový převod 18.19)

Synchronous electric drives with permanent magnets were used as a powertrain for the electric quad prototype. These drives can operate in power as well as generator mode. There are basically two construction solutions. Firstly a motor with a rotor shaft (common arrangement), or a motor with a shaft stator (wheel hub configuration). Both variants were processed as a computer model and were manufactured.

For the first technical solution the motor with the rotor on the shaft was chosen. The PERM PMS 100 motor in 48V - $6000 \mathrm{rpm}$ specification was selected (Table 1). The efficiency of PERM PMS 100 is shown in Figure 2. The motor rpm and torque characteristics require a gearbox, so the placement of the drive was the same as for the original combustion engine (Figure 3).

Thus a constant ratio gearbox was added to the motor and the power was transferred to the rear axle by chain, utilizing the same power transmission as for the original combustion engine. The advantage of this universal placement is the easy substitution of the combustion engine with the electric motor. Therefore minimum vehicle changes are required. On the other hand, the main disadvantage of this design is the permanent ratio drive.

There is no suitable gearbox available on the market, particularly if the basic expectation was an electric drive with $14 \mathrm{~kW}, 60 \mathrm{Nm}$ peak torque and maximum $18000 \mathrm{rpm}$. All gearboxes for this power range have maximum $6000 \mathrm{rpm}$ and weight at least $40 \mathrm{~kg}$. Finally, it was necessary to build our own gearbox. By using the semi-finished products, the permanent ratio gearbox with three steps using frontal toothing was designed and produced (see Figure 4).

As the first technical solution was problematic due to finding the right gearbox and the only simplification is an easy swap of the electric motor for the combustion engine, we decided to

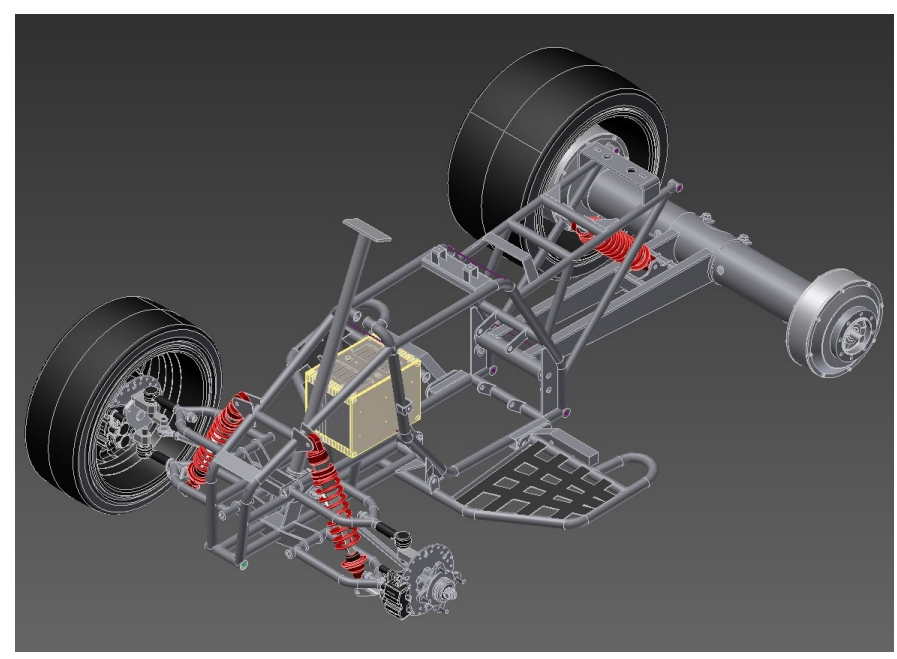

FIGURE 5: CAD model - a quad with Akumoto wheel drives OBRÁZEK 5: CAD model - čtyřkolové vozidlo s kolovými elektromotory Akumoto

use the other solution with two wheel motors on the rear axle (Figure 5). Motors for this construction were from the Akumoto 600 scooter. These motors are designed for in-wheel application; therefore no other gear is needed.

Because the rim is also a part of the stock engine, and on the scooter the motor is mounted with outlets on both sides (Figure 6 - top), it was necessary to make some changes. The shaft was shortened, the original rim was cut off and the external side of the motor was modified for mounting on the quad rear wheel (Figure 6 - bottom).
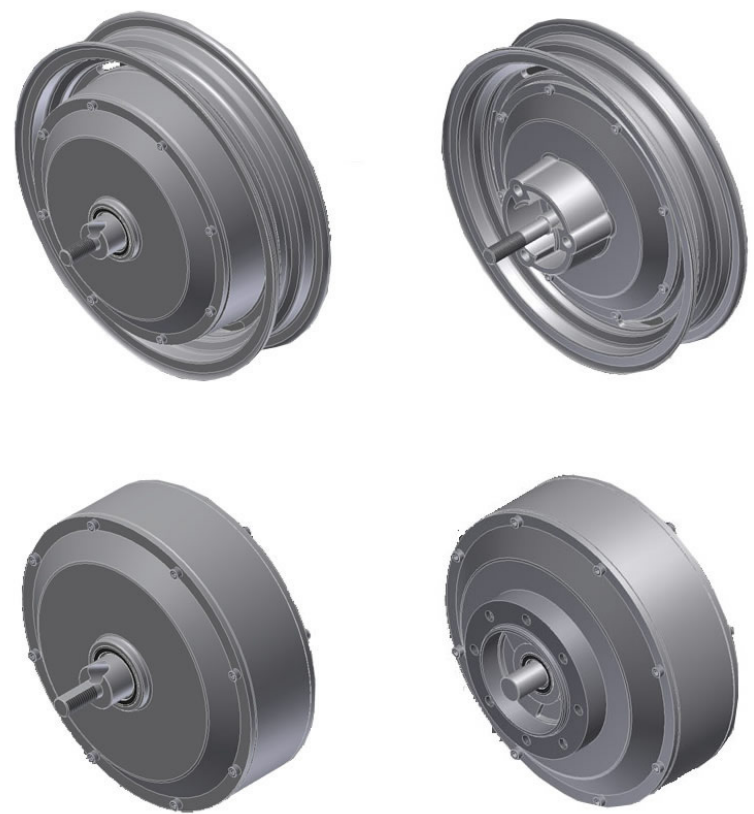

FIGURE 6: Electric Drives Akumoto 600, stock (top), modified (bottom) OBRÁZEK 6: Elektrické pohony Akumoto 600, produkční (nahoře), modifikované (dole) 
TABLE 2: KOKAM cell basic parameters

TABULKA 2: KOKAM základní parametry článku

\begin{tabular}{lcc}
\hline ITEM & VALUE & REMARK \\
\hline Rated capacity & $\begin{array}{c}\text { Typ. 17.0 Ah } \\
\text { Min. 16.4 Ah }\end{array}$ & $\begin{array}{c}\text { Charge at 0.2C (3.2 A) } \\
\text { Discharge at 0.5C (8.0 A) }\end{array}$ \\
\hline Nominal Voltage & $3.7 \mathrm{~V}$ & \\
\hline Lower limit voltage & $2.7 \mathrm{~V}$ & \\
\hline Upper limit voltage & $4.2 \pm 0.03 \mathrm{~V}$ & \\
\hline $\begin{array}{l}\text { Max. Conti. Charge } \\
\text { Current }\end{array}$ & $48 \mathrm{~A}$ & $\begin{array}{c}\text { Cnd Condition: } 0.05 \mathrm{C}(0.8 \\
\text { A) or } 5 \text { Hr Temperature: } \\
23 \pm 3^{\circ} \mathrm{C}\end{array}$ \\
\hline $\begin{array}{l}\text { Max. Conti. Discharge } \\
\text { Current }\end{array}$ & $128 \mathrm{~A}$ & \\
\hline Peak Discharge Current & $160 \mathrm{~A}$ & Less than $10 \mathrm{~s}$ \\
\hline
\end{tabular}

TABLE 3: Electric drives comparison

TABULKA 3: Porovnání pohonů

\begin{tabular}{lccc}
\hline ITEM & VALUE & VALUE & REMARK \\
\hline Drive & PERM PMS 100 & $2 \times$ Akumoto 600 & \\
\hline Power $P_{\text {nom }}$ & $2.7 \mathrm{~kW}$ & $2 \times 3 \mathrm{~kW}$ & \\
\hline Measured $\mathrm{P}_{\max }$ & $5.1 \mathrm{~kW}$ & $5.9 \mathrm{~kW}$ & \\
\hline Measured $\mathrm{I}_{\max }$ & $96 \mathrm{~A}$ & $110 \mathrm{~A}$ & During the test \\
\hline Voltage $\mathrm{U}_{\text {bat }}$ & $54 \mathrm{~V}$ & $54 \mathrm{~V}$ & Start of the test \\
\hline $\begin{array}{l}\text { Power } \\
\mathrm{P}_{2} \text { calculated }\end{array}$ & $5.18 \mathrm{~kW}$ & $5.94 \mathrm{~kW}$ & $\begin{array}{c}\text { Based on values } \\
\mathrm{U}_{\text {bat }} \text { and } \mathrm{I}_{\max }\end{array}$ \\
\hline Speed $\mathrm{v}_{\max }$ & $31 \mathrm{~km} / \mathrm{h}$ & $46 \mathrm{~km} / \mathrm{h}$ & \\
\hline
\end{tabular}

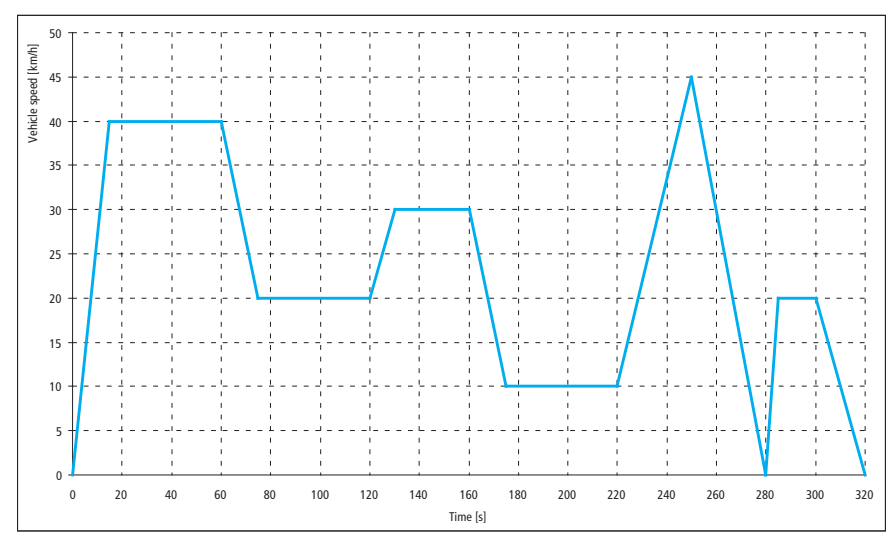

FIGURE 7: Test driving cycle

OBRÁZEK 7: Testovací cyklus

It can also be seen from Figure 5 that this construction required rear axle modifications for mounting of the power-train units. The advantage of the drivetrain setup with in-wheel motors is the simplicity arising from the fact that no gears are required. Thanks to the torque driving management of the motor, the power transfer is optimised and in addition it substitutes the limited slip differential in the drive train construction. The disadvantage of this design is a significant increase of the un-sprung weight. In the case of commercial production
TABLE 4: Measured passive resistances TABULLKA 4: Měřené pasivní ztráty

\begin{tabular}{cccc}
\hline $\begin{array}{c}\text { Speed } \\
{[\mathrm{km} / \mathrm{h}]}\end{array}$ & $\begin{array}{c}\text { Test bed } \\
\text { losses without } \\
\text { vehicle [N] }\end{array}$ & $\begin{array}{c}\text { Test bed } \\
\text { losses with } \\
\text { vehicle and driver [N] }\end{array}$ & $\begin{array}{c}\text { Vehicle losses } \\
\text { with driver [N] }\end{array}$ \\
\hline 10 & 77.40 & 116.26 & 38.86 \\
\hline 15 & 92.58 & 136.57 & 44.00 \\
\hline 20 & 104.29 & 151.81 & 47.52 \\
\hline 25 & 112.96 & 163.19 & 52.23 \\
\hline 30 & 121.06 & 173.73 & 52.67 \\
\hline 35 & 129.89 & 183.04 & 53.15 \\
\hline 40 & 136.30 & 193.80 & 57.50 \\
\hline 45 & 144.64 & 203.46 & 58.83 \\
\hline 50 & 154.32 & 214.12 & 59.80 \\
\hline
\end{tabular}

this problem can be partially solved by using a different axle construction and lighter materials.

Accumulators developed by TREMONDI were used as the energy source. These accumulators are based on the SLPB (Superior Lithium Polymer Battery) cells produced by KOKAM (a South Korean producer). A thirteen-cell battery gives the voltage Unom $=48.1 \mathrm{~V}$ and the capacity $16 \mathrm{Ah}(0.76 \mathrm{kWh})$. This accumulator has compact dimensions $(215 \times 158 \times 134 \mathrm{~mm})$ and low weight $(7.7 \mathrm{~kg})$. Another advantage is the minimum voltage drop under high current consumption. During the tests the measured voltage drop was only $2.5 \mathrm{~V}$ at a current consumption of 100-110 A. Basic characteristics of the KOKAM battery cell are presented in Table 2 .

Both construction solutions were subjected to basic power tests. In addition, battery endurance tests were performed for the variant with in-wheel drives. Measurements were taken on the SAXON rolling chassis dynamometer at the Mendel University in Brno labs. This test bed has a double roller configuration. This device was chosen for its easy mounting and due to the lowest inertial weight available at the university test facility $(790 \mathrm{~kg}$ with quad prototype and driver). Nevertheless, its relatively high inertial weight distorts the measured values, and thus it was taken into account when evaluating the results. For the battery endurance tests we used the test cycle presented in Figure 7. Colours are used for the theoretical cycle, red lines represent acceleration, grey is a constant speed interval and green lines indicate deceleration. The black dashed line shows an example of the real measured test cycle.

The accelerator position was always set to $100 \%$ during acceleration. The only exception was initial acceleration $(\mathrm{v}<5 \mathrm{~km} / \mathrm{h})$, when the value had to be lowered because of wheel spin. All deceleration was realized only by the recuperation breaking, since there are no mechanical brakes mounted on the rear axle yet. 
Acceleration

\begin{tabular}{lcccccccc}
\hline Speed $[\mathrm{km} / \mathrm{h}]$ & $0-5$ & $5-10$ & $10-15$ & $15-20$ & $20-25$ & $25-30$ & $30-35$ & $35-40$ \\
\hline Hill [ $\left.{ }^{\circ}\right]$ & 14.02 & 15.07 & 13.86 & 11.37 & 8.37 & 6.52 & 4.86 & 3.40 \\
\hline Hill [\%] & 28.04 & 30.14 & 27.71 & 22.73 & 16.74 & 13.04 & 9.72 \\
\hline Fixed speed & & & & & & & & \\
\hline Speed $[\mathrm{km} / \mathrm{h}]$ & 5 & 10 & 15 & 20 & 25 & 30 & 35 & 40 \\
\hline Hill $\left[^{\circ}\right]$ & 1.25 & 1.78 & 2.12 & 2.37 & 2.57 & 2.76 & 2.93 & 3.08 \\
\hline Hill $[\%]$ & 2.50 & 3.56 & 4.24 & 4.74 & 5.14 & 5.48 & 5.86 & 6.16 \\
\hline
\end{tabular}

\section{RESULTS}

Comparison of both construction variants is listed in Table 3 . During the tests many differences were identified between the control units of the drives. The Perm motor management allows direction changes forward/backward with electronic control and the drive power in motor and generator mode is the same. Since the Akumoto drives come originally from a small scooter, there is no electronic control of the rotation direction. Only the setup enables the recognition of forward motion. Also the power in generator mode is lower (approximately $50 \%$ ) than in motor mode.

The battery endurance tests were accomplished on the quad equipped with in-wheel drives only. It has to be emphasized that the inertial weight and passive losses of the test bed are much bigger than the inertial weight and losses of the vehicle with driver (Tabule 4). These facts were included in the evaluation, concluding that the test cycle does not correspond to a horizontal track, but rather represents an uphill climb. The hill inclination change depends on the actual speed and acceleration levels. Table 5 presents calculated values of inclination, according to constant speed and acceleration (average value in fixed span). The hill inclination appropriate to a speed of $0-5 \mathrm{~km} / \mathrm{h}$ is lower than at a speed of $5-10 \mathrm{~km} / \mathrm{h}$, because of the wheel spin, as was mentioned above, the setup of the accelerometer was not $100 \%$. Calculation indicates that for an approximately $2 \mathrm{~km}$ long track the vehicle overcomes a vertical distance of up to $130 \mathrm{~m}$. During the endurance tests with one accumulator $48 \mathrm{~V} / 16 \mathrm{Ah}$ the vehicle finished on average 6 test cycles, that is $12 \mathrm{~km}$ with a vertical distance of around $700 \mathrm{~m}$. In accordance with customers' requirements, many attributes were measured (battery temperature, ECU temperatures, drive temperatures, current at fixed speed etc.). Average values of the measured attributes are presented in Table 6 . The full capacity of the battery was not used, because the ECUs have inbuilt accumulator protection so when the voltage drops below $42 \mathrm{~V}$ the drives are disconnected.

\section{CONCLUSION}

This article has presented two construction solutions of the drivetrain for an electric powered quad and shows the advantages and disadvantages of each variant. It shows that the variant with in-wheel drives leaves higher available space for batteries (up to 4), which can significantly extend the range. This type of construction may also be promising for passenger cars or small lorries, where the increase of un-sprung weights is not as significant compared to weight of the whole vehicle, when compared to the quad. In particular it will be suitable if the potential worsening of handling can be partly eliminated using active damper units. As for the tested accumulators, usage of high density cells with lightweight constructions seems to be the only possible way for future prospects [4]. However, until the battery prices drop, the full hybrid cars with combustion engines and micro-turbines as generators and range extenders remain a feasible alternative. In the near future, one can expect progress in the construction of new in-wheel drives, which will bring better torque and rpm characteristics as well as being lightweight, and they will be part of the hub and rim, such as those on motorbikes.

TABLE 6: Battery measured values

TABULKA 6: Hodnoty měřené při zkoušení akumulátorů

\begin{tabular}{lcc}
\hline ITEM & VALUE & REMARK \\
\hline Battery voltage - test start & $54 \mathrm{~V}$ & \\
\hline Battery voltage - test end & $42.4 \mathrm{~V}$ & \\
\hline $\begin{array}{l}\text { Max. Battery voltage drop by high } \\
\text { current consumption }\end{array}$ & $2.5 \mathrm{~V}$ & \\
\hline $\begin{array}{l}\text { Current consumption: } \\
\text { Max }\end{array}$ & $110 \mathrm{~A}$ & \\
$\begin{array}{l}\text { At } 10 \mathrm{~km} / \mathrm{h} \\
\text { At } 20 \mathrm{~km} / \mathrm{h}\end{array}$ & $10 \mathrm{~A}$ & \\
$\begin{array}{l}\text { At } 30 \mathrm{~km} / \mathrm{h} \\
\text { At } 40 \mathrm{~km} / \mathrm{h}\end{array}$ & $34 \mathrm{~A}$ & \\
\hline Max. Recuperation current & $53 \mathrm{~A}$ & \\
\hline $\begin{array}{l}\text { Average rise of Battery temp. during } 1 \\
\text { measurement }\end{array}$ & $30 \mathrm{~A}$ & \\
\hline $\begin{array}{l}\text { Average rise of motor temp. during } 1 \\
\text { measurement }\end{array}$ & $10.4{ }^{\circ} \mathrm{C}$ & $\begin{array}{c}1 \text { measurement } \\
=6 \text { cycles }\end{array}$ \\
\hline
\end{tabular}




\section{ACKNOWLED GEMENTS}

This work was supported by IGA TP2/2012 Implementation of network protocol based on SAE J1939 recommendation in agricultural tractor.

This work was part of the project DOPSIT Reg. No. CZ.1.07/2.3.00/20.0226 funded under the Operational Program Education for Competitiveness.

This study was accomplished in cooperation with TREMONDI s.r.o.

\section{REFERENCES}

[1] Boretti A. A. (2012). Energy recovery in passenger cars. Journal of Energy Resources Technology. Vol. 134, No. 2. p. 8. ISSN: 0195-0738.

[2] Freyermuth V., Fallas E., Rousseau A. (2009). Comparison of powertrain configuration for plug-in hevs from a fuel economy perspective. SAE International Journal of Engines. Vol. 1, No 1, pp. 392-398. ISSN: 1946-3936.

[3] Joelsson J., Gustavsson L. (2012). Swedish biomass strategies to reduce $\mathrm{CO}_{2}$ emission and oil use in an EU context. Energy. Vol. 43, No. 1, pp. 448-468.

ISSN: 0360-5442.

[4] Lunz B., Yan Z, Gerschler J. B., Sauer D. U. (2012). Influence of plug-in hybrid electric vehicle charging strategies on charging and battery degradation costs. Energy Policy, Vol. 46., p. 511-519. ISSN: 0301-4215

[5] Prasanth V., Bauer P., Ildiko P. (2012). Drivetrain of electric car: Development of virtual laboratory for E-learning, p. 6, ISBN: 978-1-4577-1072-8

[6] Weiss M., Patel M. K., Junginger M., Perujo A., Bonnel P., Grootveld G. (2012). On the electrification of road transport - Learning rates and price forecasts for hybridelectric and battery-electric vehicles. Energy Policy, Vol. 48, p. 347-393, ISSN: 0301-4215 